\title{
ANALISIS KARAKTERISTIK PERUSAHAAN DAN ENVIRONMENTAL PERFORMANCE TERHADAP ENVIRONMENTAL DISCLOSURE
}

\author{
Dendi Purnama \\ dendipurnama90@gmail.com \\ Universitas Kuningan
}

\begin{abstract}
This study aims to analyze the effect of profitability, leverage, company size, and environmental performance to environmental disclosure. The population in this study are all manufacturing companies listed on the Indonesia Stock Exchange from 2014 until 2016. The sample in this study were 71 companies for 3 years. The method of analysis used in this study is multiple regression analysis.

The results show that profitability and leverage have no effect on environmental disclosure, while firm size and environmental performance have positive effect on environmental disclosure. Taken together, the variables of profitability, leverage, firm size and environmental performance have significant effect on environmental disclosure.
\end{abstract}

Keywords: Profitability; Leverage; Size; Environmental Performance; Environmental Disclosure 


\section{PENDAHULUAN}

Pengelolaan lingkungan hidup diatur dalam Undang-Undang Dasar Negara Republik Indonesia No. 23 Tahun 1997 tentang pasal 5 yang menyatakan bahwa lingkungan hidup yang baik dan sehat merupakan hak asasi dan hak konstitusional bagi setiap warga negara Indonesia, dan mempunyai hak atas informasi lingkungan hidup yang berkaitan dengan peran dalam pengelolaan lingkungan hidup. Oleh karena itu, negara, pemerintah dan seluruh pemangku kepentingan berkewajiban untuk melalukan perlindungan dan pengelolaan lingkungan hidup dalam pelaksanaan pembangunan berkelanjutan agar lingkungan hidup Indonesia dapat menjadi sumber dan penunjang hidup bagi rakyat Indonesia serta makhluk hidup lain. Pembangunan berkelanjutan adalah upaya sadar dan terencana yang memadukan aspek lingkungan hidup, sosial, dan ekonomi ke dalam strategi pembangunan untuk menjamin keutuhan lingkungan hidup serta keselamatan, kemampuan, kesejahteraan dan mutu hidup generasi masa kini dan generasi masa depan. Proses pembangunan berkelanjutan bertumpu pada faktor kondisi sumber daya alam, kualitas lingkungan dan kependudukan. Oleh karena itu, upaya pembangunan berwawasan lingkungan perlu memuat ikhtiar pembangunan yang memelihara keutuhan dan fungsi tatanan lingkungan dan dalam proses pembangunan berkelanjutan ini, tidak terlepas dari akibat buruk terhadap lingkungan yaitu pencemaran atau perusakan lingkungan.

Pencemaran lingkungan adalah perubahan pada lingkungan yang tidak dikehendaki karena dapat memengaruhi kegiatan, kesehatan, dan keselamatan makhluk hidup. Perubahan tersebut disebabkan oleh suatu zat pencemar yang disebut polutan dan disebabkan dengan banyaknya kegiatan industri yang saat ini sedang terjadi di berbagai negara menyebabkan keseimbangan lingkungan mulai berubah Di Indonesia kegiatan industri masih perlu untuk diperhatikan oleh pemerintah. Sebab masih banyak perusahaan yang belum memberikan kepeduliannya terhadap lingkungan. Selain itu, kurangnya perhatian pemerintah dalam peraturan pengelolahan lingkungan menyebabkan perusahaan banyak melakukan eksploitasi besar-besaran terhadap sumber daya alam karena perusahaan lebih mengutamakan kepentingan untuk memperoleh laba dan berorientasi pada kepentingan pemilik modal yang menyebabkan perusahaan melakukan eksploitasi sehingga mengakibatkan kerusakan lingkungan hidup yang pada akhirnya mengganggu kehidupan manusia (Anggraini, 2006).

\section{Enviromental dislcosure}

merupakan pengungkapan informasi yang berkaitan dengan lingkungan di dalam laporan tahunan perusahaan (Suratno et al., 2006). Deegan dan Brown (1998) mengatakan environmental disclosure penting untuk dilakukan karena melalui pengungkapan lingkungan hidup pada laporan tahunan perusahaan, masyarakat dapat memantau aktivitas-aktivitas yang dilakukan oleh perusahaan dalam rangka memenuhi tanggung jawab sosialnya.

Berbagai faktor yang menjadi penyebab perusahaan melakukan pengungkapan informasi lingkungan dalam annual report seperti corporate governance dan karakteristik perusahaan. Karakteristik perusahaan merupakan ciri khas atau sifat yang melekat dalam suatu entitas usaha yang dapat dilihat dari beberapa segi, diantaranya jenis usaha atau industri 
, struktur kepemilikan, tingkat likuiditas, tingkat profitabilitas, dan ukuran perusahaan (Safitri, 2008). Dalam penelitian ini karakteristik perusahaan yang digunakan meliputi profitabilitas, leverage, dan ukuran perusahaan.

Profitabilitas merupakan tingkat keuntungan yang berhasil diperoleh perusahaan dalam menjalankan operasionalnya. Semakin tinggi profitabilitas perusahaan maka semakin tinggi pula disclosure perusahaan.

Namun, beberapa penelitian terdahulu mengenai profitabilitas yang mempengaruhi environmental disclosure belum menunjukkan hasil yang konsisten. Suhardjanto dan Miranti (2007) dan Putri (2015) dalam penelitiannya membuktikan adanya korelasi positif antara profitabilitas dan pengungkapan lingkungan perusahaan. Hal ini sejalan dengan penelitian Robert (1992) yang menemukan bukti bahwa profitabilitas mempunyai hubungan dengan pengungkapan lingkungan. Namun, berbeda dengan penelitian yang dilakukan oleh Sudaryono (2006) dan Suhardjanto (2010) yang menyatakan bahwa profitabilitas tidak berpengaruh terhadap pengungkapan lingkungan.

Leverage keuangan adalah penggunaan sumber dana yang menimbulkan beban tetap keuangan. Semakin tinggi rasio leverage semakin rendah pengungkapannya karena semakin tinggi tingkat leverage maka semakin besar kemungkinan perusahaan akan melanggar perjanjian kredit (Suhardjanto, 2010). Hal ini sejalan dengan Jensen dan Meckling (1976) yang menyatakan perusahaan yang memiliki leverage yang tinggi akan mengurangi disclosure yang dibuatnya untuk mengurangi sorotan dari Bondholder. Beberapa penelitian terdahulu mengenai profitabilitas yang berpengaruh terhadap environmental disclosure. Suhardjanto (2010) memberikan pernyataan tentang pengaruh leverage berpengaruh negatif terhadap pengungkapan lingkungan. Penelitian Suhardjanto dan Miranti (2007) yang menyatakan bahwa leverage tidak berpengaruh terhadap pengungkapan lingkungan. Namun, berbeda dengan penelitian yang dilakukan oleh Putri (2015) yang menyatakan bahwa leverage berpengaruh positif terhadap pengungkapan lingkungan.

Adapun faktor lain yang mempengaruhi environmental disclosure yaitu environmental performance yang merupakan kinerja perusahaan dalam menciptakan lingkungan yang baik (Suratno et al., 2006). Environmental performance diukur berdasarkan pada peringkat kinerja yang diperoleh perusahaan dalam PROPER. PROPER merupakan salah satu program unggulan kementrian lingkungan hidup yang berupa kegiatan pengawasan dan pembinaan terhadap penanggungjawab usaha dan/atau kegiatan di bidang pengendalian pencemaran dan/atau kerusakan lingkungan hidup serta pengelolaan limbah B3. Penghargaan PROPER bertujuan untuk mendorong perusahaan untuk taat terhadap peraturan lingkungan hidup dan mencapai keunggulan lingkungan (environmental excellency). Hal ini dinilai dari pemenuhan ketentuan dalam izin lingkungan, pengendalian pencemaran air, pengendalian pencemaran udara, pengelolaan limbah B3, dan pengendalian kerusakan lingkungan.

Penelitian empiris terdahulu mengenai hubungan antara environmental performance dan environmental disclosure belum menunjukkan hasil yang konsisten. Ingram dan Frazier (1980) menemukan tidak adanya hubungan yang signifikan dalam pengujian hubungan antara 
environmental disclosure dengan environmental performance. Pattern (2002) menemukan hubungan yang negatif antara environmental disclosure dalam annual report dengan environmental performance. Gladia dan Rahardja (2013) serta Suratno et al. (2006) menyatakan bahwa environmental performance berpengaruh positif terhadap environmental disclosure.

Berdasarkan uraian di atas dan hasil dari penelitian-penelitian terdahalu yang berbeda-beda sehingga adanya fenomena gap dan research gap, dan perbedaan penelitian ini dengan penelitian terdahulu dimana sampel yang variable dan sampel penelitian yang digunakan berbeda. maka penulis tertarik untuk melakukan peneltian yang berjudul "Analisis Pengaruh Profitabilitas, Leverage, Ukuran Perusahaan, Environmental Performance terhadap Environmental Disclosure"

\section{KERANGKA TEORITIS DAN PENGEMBANGAN HIPOTESIS}

Agency Theory (Teori Keagenan)

Jensen dan Meckling (1976)

menyatakan bahwa teori agensi (agency theory) merupakan kumpulan kontrak (nexus of contract) antara pemilik sumber daya ekonomis (principal) dan manajer (agent) yang mengurus penggunaan dan pengendalian sumber daya tersebut. Dalam konsep teori akuntansi, manajemen sebagai agen seharusnya melakukan tindakan yang selaras dengan kepentingan prinsipal, namun manajemen dapat melakukan tindakan-tindakan yang hanya memaksimalkan kepentingan sendiri.

Pengungkapan didalam laporan tahunan dapat mengatasi informasi asimetris yang terjadi dalam perusahaan. Adanya asimetri informasi seringkali terjadi pada perusahaan karena pihak agen mempunyai kepentingan yang berbeda dengan pihak prinsipal. Sehingga, dengan adanya pengungkapan yang dilakukan perusahaaan dapat mengurangi konflik keagenan.

\section{Legitimacy Theory (Teori Legitimasi)}

Dowling dan Pfeffer (1975) menyatakan teori legitimasi sangat bermanfaat dalam menganalisis perilaku organisasi dan menjadi sumber yang menentukan keberadaan perusahaan. Perusahaan dikatakan memiliki legitimasi ketika sistem nilai perusahaan sejalan dengan sistem nilai masyarakat. Teori legitimasi menjelaskan kontrak sosial organisasi dengan masyarakat, kelangsungan hidup perusahaan akan terancam jika masyarakat merasa organisasi telah melanggar kontrak sosialnya.

Perusahaan melakukan pengungkapan lingkungan untuk memberikan informasi yang lebih luas kepada masyarakat tentang kepedulian perusahaan terhadap lingkungan sehingga keberadaan perusahaan dapat diterima oleh masyarakat.

\section{Profitabilitas terhadap Environmental Disclosure}

Perusahaan dengan rasio profitabilitas yang tinggi dapat mengungkapkan informasi yang lebih luas untuk mencegah penilaian yang negatif (De Villiers dan Van Stade, 2011) dan untuk meningkatkan kredibilitas perusahaan dimata investor (Cormier dan Magnan, 1999). Penelitian yang dilakukan oleh (Suhardjanto dan Miranti, 2007) menyatakan bahwa profitabilitas perusahaan memiliki hubungan yang positif artinya semakin tinggi profitabilitas perusahaan maka semakin tinggi pula disclosure. 
Berdasarkan uraian di atas, maka hipotesis yang diajukan sebagai berikut:

\section{Leverage terhadap Environmental Disclosure}

Leverage menggambarkan seberapa besar perusahaan dibiayai oleh utang untuk membiayai investasinya. Semakin besar utang perusahaan maka semakin besar risiko yang dihadapi perusahaan. Manajemen perusahaan dengan tingkat leverage yang tinggi akan mengurangi pengungkapan tanggung jawab lingkungan yang dibuatnya agar tidak menjadi sorotan dari para debtholders (Suhardjanto, 2010). Dengan demikian,

\section{Ukuran Perusahaan terhadap Environmental Disclosure}

Perusahaan besar merupakan emiten yang disoroti, karena pihak eksternal akan melihat mengenai hasil operasinya dari pengungkapan yang dilakukan oleh perusahaan besar. Hal ini sesuai dengan teori agensi, dimana perusahaan besar akan mengungkapkan informasi yang luas untuk dapat mengurangi konflik keagenan. Hal ini sejalan dengan pendapat Hackson dan Milne (1996), serta Trotman dan Bradley (1981) bahwa perusahaan lebih besar melakukan aktivitas yang lebih banyak pula sehingga memberikan dampak yang lebih besar pula terhadap lingkungan, sehingga lebih banyak pula shareholder maupun stakeholder yang peduli terhadap program lingkungan yang dijalankan oleh perusahaan. Perusahaan besar mendapat perhatian besar dari media, pembuat keputusan dan stakeholder lainnya sehingga perusahaan besar berupaya mengungkapkan lebih banyak informasi lingkungan kepada para pemangku kepentingan perusahaan (Suhardjanto, 2010). Penelitian yang dilakukan Suhardjanto (2010) dan Ekbas (2014) menyatakan bahwa ukuran perusahaan
H1: Profitabilitas berpengaruh positif terhadap environmental disclosure Leverage berpengaruh negatif terhadap environmental disclosure. Hal ini dikarenakan perusahaan yang memiliki leverage yang tinggi akan mengurangi disclosure perusahan dengan tujuan untuk mengurangi sorotan dari bondholder (Jensen dan Meckling, 1976; Belkaoui dan Karpik, 1989; serta Suhardjanto, 2010). Berdasarkan uraian di atas, maka hipotesis yang diajukan sebagai berikut:

$\mathrm{H} 2$ : Leverage berpengaruh negatif terhadap environmental disclosure.

berpengaruh positif terhadap environmental disclosure Berdasarkan uraian di atas, maka hipotesis yang diajukan sebagai berikut:

H3: Ukuran perusahaan berpengaruh positif terhadap environmental disclosure

\section{Environmental Performance terhadap Environmental Disclosure}

Perusahaan yang memiliki kinerja lingkungan yang baik akan melakukan pengungkapan lingkungan yang lengkap dan transparan untuk memposisikan sebagai perusahaan yang memiliki aktivitas yang berguna serta tingkat pengungkapan tersebut didorong oleh legitimasi terhadap masyarakat. Oleh karena itu, semakin tinggi kualitas kinerja lingkungan suatu perusahaan maka perusahaan akan semakin meningkatkan kualitas informasi yang diungkapkan dalam laporan lingkungan (Gladia dan Rahardja, 2013). Menurut Al-Tuwaijiri et al. (2004) terdapat hubungan positif antara enviromental performance dengan environmental disclosure. Hasil pengujian tersebut didukung okeh penelitian yang dilakukan Lindrianasari (2007) yang menguji kinerja lingkungan 
berpengaruh positif terhadap pengungkapan lingkungan. Berdasarkan uraian tersebut, dalam penelitian ini diajukan hipotesis sebagai berikut:

\section{METODOLOGI}

Metode penelitian yang digunakan dalam penelitian ini adalah metode deskriptif dan verifikatif dengan pendekatan penelitian kuantitatif. Populasi dalam penelitian ini adalah
$\mathrm{H} 4$ : environmental performance berpengaruh positif terhadap environmental disclosur

seluruh perusahaan manufaktur yang terdaftar di Bursa Efek Indonesia tahun 2014 sampai dengan tahun 2016. Berdasarkan hasil dari purposive sampling method dimana pengambilan sampel dilakukan berdasarkan pertimbangan dan memenuhi kriteria sebagai berikut:

Tabel 1.

Sampel Perusahaan

Perusahaan Manufaktur di BEI Periode Tahun 2014 sampai 2016

\begin{tabular}{clllc}
\hline No & \multicolumn{1}{c}{ Keterangan } & $\begin{array}{c}\text { Jumlah } \\
\text { Perusahaan }\end{array}$ \\
\hline 1. & $\begin{array}{l}\text { Perusahaan manufaktur yang listing di BEI secara } \\
\text { berturut-turut periode tahun 2010-2015 }\end{array}$ & 140 \\
\hline 2 & $\begin{array}{l}\text { Perusahaan manufaktur di BEI yang tidak } \\
\text { mempublikasikan laporan tahunan (annual report) dan }\end{array}$ & $(34)$ \\
& $\begin{array}{l}\text { tidak memiliki laporan tahunan secara lengkap dari } \\
\text { periode tahun 2014-2016 }\end{array}$ & \\
\hline 3 & $\begin{array}{l}\text { Perusahaan manufaktur yang tidak mengungkapkan } \\
\text { mengenai keikutsertaan penilaian peringkat kinerja } \\
\text { perusahaan (proper) dalam pengelolaan lingkungan hidup }\end{array}$ & $(35)$ \\
\hline
\end{tabular}

\section{Operasional Variabel Dependen}

\section{A. Environmental Disclosure}

Variabel dependen dalam penelitian ini adalah environmental disclosure (Y). Environmental disclosure diproksikan dengan menggunakan skor pengungkapan environmental disclosure pada annual report perusahaan sampel. Skor diberikan pada setiap item pengungkapan aktivitas lingkungan hidup yang terdapat dalam annual report. Bobot skor yang digunakan adalah menggunakan Indonesian Environmental Reporting Index (IER) yang merupakan hasil penelitian dari Suhardjanto, Tower dan Brown (2007). Penggunaan skor ini dipilih karena bobot yang diberikan sesuai dengan pengungkapan informasi lingkungan hidup pada perusahaan di Indonesia sehingga hasilnya akan lebih tepat dan akurat.

Tabel 2. Indonesian Environmental Reporting Indeks (IER)

No IER Items IER Index




\begin{tabular}{ll}
\hline 1. Impact of Using Water & 3.05 \\
2. Incidents and Fines & 2.27 \\
3. Programs for Protection & 1.99 \\
4. Waste by Type & 1.91 \\
5. Impacts of Activities & 1.84 \\
6. Materials by Type & 1.63 \\
7. Environmental Expense & 1.58 \\
8. Discharges Water & 1.54 \\
9. Other Air Emissions & 1.44 \\
10. Withdrawals of Ground Water & 1.43 \\
11. Land Information & 1.41 \\
12. Volume of Water Use & 1.29 \\
13. Energy Consumption & 1.25 \\
14. Performance of Supplier & 1.05 \\
15. Impact of Discharges Water & 1.05 \\
16. Impacts of Transportation & 0.95 \\
17. Impacts of Products & 0.84 \\
18. Land for Extraction & 0.76 \\
19. Spills of Chemicals & 0.67 \\
20. Indirect Energy & 0.59 \\
21. Renewable Initiatives & 0.42 \\
22. Habitat Changes & 0.41 \\
23. Other Indirect Energy & 0.37 \\
24. Recycling Water & 0.36 \\
25. Hazardous Waste & 0.30 \\
26. Impermeable Surface & 0.30 \\
27. Affected Red List Species & 0.28 \\
28. Impact of Activities on Protected Areas & 0.20 \\
29. Wastes of Material & 0.19 \\
30. Direct Energy & 0.14 \\
31. Greenhouse Gas Emissions (GGEs) & 0.10 \\
32. Recycling Materials & 0.08 \\
33. Emissions of Ozone Depleting Substances & 0.02 \\
34. Other Indirect GGEs & 0.02 \\
35. Operations in Protected Areas & 1.00 \\
\hline
\end{tabular}

\section{Operasional}

\section{Independen}

\section{A. Profitabilitas}

Profitabilitas dalam penelitian ini menggunakan Return on Asset (ROA). ROA digunakan untuk mengukur kemampuan manajemen dalam memperoleh keuntungan (laba) secara keseluruhan.
Menurut Kasmir (2011) Return on Asset (ROA) diukur dengan menggunakan rumus:

$$
R O A=\frac{\text { Laba bersih setelah pajak }}{\text { total aset }}
$$




\section{B. Leverage}

Leverage merupakan rasio yang menunjukan kuantitas hutang atau kewajiban perusahaan terhadap total aset

$$
\text { DER }=\frac{\text { Total hutang }}{\text { total equity }}
$$

\section{Ukuran perusahaan}

Ukuran perusahaan adalah skala untuk menentukan besar kecilnya perusahaan yang dihitung dengan menggunakan logaritma natural dari total aktiva,

\section{Environmental}

\section{Performance}

Environmental Performance adalah kinerja perusahaan dalam menciptakan lingkungan yang baik (Suratno et al., 2006). Environmental performance diukur berdasarkan pada peringkat kinerja yang diperoleh perusahaan dalam PROPER. PROPER merupakan program yang dibuat oleh Kementerian Lingkungan Hidup (KLH) untuk mendorong penaatan perusahaan dalam pengelolaan lingkungan hidup melalui instrumen informasi. Sistem
(Solihin, 2009). Menurut Wild dan Subramanyam 2009) rumus debt to equity ratio adalah sebagai berikut:

sehingga dapat dirumuskan sebagai berikut (Budiasih, 2009).

Firm Size $=$ Ln Total Aset

penilaian kinerja PROPER ditunjukkan oleh warna sesuai dengan peringkat kinerja. Terdapat lima peringkat warna dengan yaitu emas, hijau, biru, merah dan hitam. Warna emas merupakan peringkat tertinggi berurutan dengan warna lain hingga warna hitam sebagai peringkat terendah. Pengukuran kinerja lingkungan dalam penelitian ini dengan memberikan nilai sesuai dengan peringkat warna yang diperoleh perusahaan. Nilai berdasarkan peringkat perusahaan

Tabel 3. Nilai Berdasarkan peringkat PROPER

\begin{tabular}{lc}
\hline \multicolumn{1}{c}{ Peringkat Warna } & Nilai \\
\hline Emas & 5 \\
Hijau & 4 \\
Biru & 3 \\
Merah & 2 \\
Hitam & 1 \\
\hline
\end{tabular}


HASIL DAN PEMBAHASAN

Statistik Deskriptif

Hasil pengukuran statistik deskriptif dalam penelitian ini untuk variabel independen berupa nilai minimum dan maksimum, nilai rata-rata serta deviasi standar dapat dilihat pada tabel berikut ini.

\section{Tabel 4.}

\section{Hasil Statistik Deskriptif}

\begin{tabular}{lcrrrr}
\hline & $\mathrm{N}$ & Minimum & Maximum & Mean & Std. Deviation \\
Profitabilitas & 213 &,- 2898 &, 4317 &, 0374 &, 0858 \\
Leverage & 213 & $-4,9342$ & 8,2613 & 1,1901 & 1,4975 \\
Ukuran & 213 & 25,0092 & 32,1508 & 28,1448 & 1,7512 \\
Perusahaan & & & 5,0000 & 3,3380 &, 6787 \\
EP & 213 & 2,0000 & 11,2000 & 5,1404 & 2,2842 \\
ED & 213 & 2,0200 & & & \\
Valid N (listwise) & 213 & & &
\end{tabular}

Sumber: data diolah dari SPSS

Berdasarkan Tabel 4.1 di atas, diketahui bahwa jumlah sampel yang diobservasi dalam penelitian ini adalah sebanyak 213 laporan tahunan. Nilai minimum dari profitabilitas adalah 0,2898 , nilai maksimumnya 0,4317 , nilai rata-ratanya adalah 0,374 dan standar deviasinya adalah 0,0858 . Nilai minimum dari leverage adalah $-4,9342$, nilai maksimumnya adalah 8,2613 , nilai rata-ratanya adalah 1,1901 dan standar deviasinya adalah 1,498. Nilai minimum dari ukuran perusahaan adalah 25,0092, nilai maksimumnya adalah 32,1508, nilai rata-ratanya adalah 28,1448 dan standar deviasinya adalah 1,751. Nilai minimum dari Environmental Performance adalah 2,000 , nilai maksimumnya adalah 5,000 nilai rata-ratanya adalah 3,3380 dan standar deviasinya adalah 0,6787 . Nilai minimum dari environmental disclosure adalah 2,0200 nilai maksimumnya adalah 11,2000 nilai rata-ratanya adalah 5,1404 dan standar deviasinya adalah 2,2841 .

\section{Pembahasan}

Tabel 5.

Hasil Uji t

\begin{tabular}{lrrl}
\hline \multicolumn{1}{c}{ Model } & Koefisien & \multicolumn{1}{l}{ T } & Sig. \\
\hline (Constant) & 0,643 & 0,255 & 0,006 \\
Profitabilitas & 0,887 & 0,481 & 0,631 \\
Leverage & $-0,005$ & $-0,051$ & 0,959 \\
Ukuran Perusahaan & 0,669 & 2,731 & 0,005 \\
Environmental Performance & 0,757 & 3,169 & 0,002 \\
\hline
\end{tabular}

Sumber: data diolah dari SPSS 
Berdasarkan tabel di atas, maka dapat disusun model persamaan regresi linier berganda sebagai berikut:

$\mathrm{Y}=0,643+0,887 \mathrm{X}_{1}-0,005 \mathrm{X}_{2}+$ $0,669 X_{3}+0,757 X_{4}$

\section{Pengaruh Profitabilitas terhadap Environmental Disclosure}

Pengujian hipotesis pertama menyatakan bahwa profitabilitas tidak berpengaruh terhadap environmental disclosure. Hasil penelitian ini menunjukkan bahwa nilai $t$ hitung sebesar 0,481 dengan tingkat signifikan sebesar 0,631 yang berarti lebih besar dari 0,05 . Hasil penelitian ini sesuai dengan penelitian yang dilakukan Sudaryono (2006) dan Suhardjanto (2010) yang mengemukakan bahwa profitabilitas tidak berpengaruh environmental disclosure Hal ini mengindikasikan bahwa tingkat profitabilitas yang tinggi maupun rendah tidak akan berdampak pada perusahaan untuk mengungkapkan informasi yang berkaitan dengan environmental disclosure. Padahal environmental disclosure merupakan bagian dari corporate social responsilibilty yang ada dalam laporan tahunan yang memberikan informasi mengenai tanggung jawab perusahaan terhadap kepedulian kepada sesama maupun lingkungan. Selain itu, pihak manajemen perusahaan menganggap bahwa environmental disclosure hanya merupakan bagian dari pengungkapan sukarela dan bukan bagian pengungkapan wajib. Hal ini akan berdampak pada investor, karena para investor menilai perusahaan tidak hanya dari pengungkapan wajib namun mereka juga menilai pengungkapan sukarela.

\section{Pengaruh Leverage terhadap Environmental Disclosure \\ Pengujian hipotesis kedua} menyatakan bahwa leverage tidak berpengaruh terhadap environmental disclosure. Hasil itu terbukti dari nilai $\mathrm{t}$ yang dihasilkan sebesar -0,051 dengan tingkat signifikan 0,631 yang berarti lebih besar dari 0,05. Dengan demikian, dapat diambil kesimpulan bahwa dalam penelitian ini leverage tidak berpengaruh terhadap manajemen laba. Hasil penelitian ini sejalan dengan penelitian yang dilakukan oleh Ekbas (2014) yang menyatakan bahwa leverage tidak berpengaruh terhadap environmental dislcosure. Hal ini mengindikasikan bahwa semakin tinggi atau rendahnya leverage tidak akan mempengaruhi environmental disclosure. Hasil penelitian ini mengindikasikan bahwa leverage perusahaan tidak akan berdampak pada perusahaan dalam melakukan environmental disclosure. Meskipun environmental disclosure merupakan bagian dari corporate social responsibility. Selain itu, hasil tersebut menunjukkan bahwa informasi mengenai leverage perusahaan yang termuat dalam laporan tahunan tidak begitu bermakna bagi investor maupun kreditur.

\section{Pengaruh Ukuran Perusahaan Environmental Disclosure}

Pengujian hipotesis ketiga menyatakan bahwa ukuran perusahaan berpengaruh negatif terhadap environmental disclosure. Hasil penelitian ini menunjukkan bahwa nilai $\mathrm{t}$ hitung sebesar 2,731 dengan tingkat signifikan sebesar 0,005 yang berarti lebih kecil dari 0,05 . Hasil penelitian ini sesuai dengan penelitian yang dilakukan oleh Suhardjanto (2010), Akbas (2014), dan Putri (2015) yang menyatakan ukuran perusahaan berpengaruh positif 
signifikan terhadap environmental dislcosure. Hal ini mengindikasikan bahwa bahwa semakin besar ukuran perusahaan, maka semakin banyak informasi yang dipublikasikan mengenai environmental disclosure karena informasi yang dipublikasikan kepada pihak eksternal akan semakin transparan dan lengkap sehingga perusahaan yang berukuran besar lebih diminati oleh investor. Karena investor dalam menilai perusahaan tidak hanya dari pengungkapan wajib tetapi juga menilai dari pengungkapan sukarela. Selain itu, perusahaan harus mengungkapkan informasi tentang perlindungan dan jaminan keselamatan keryawan, mengelola limbah agar tidak mencemari lingkungan, dan tidak membuat udara terkena solusi serta perlindungan terhadap alam sekitar. Dengan mengungkapkan informasi yang detail maka keberadaan perusahaan terlegitimasi

\section{Pengaruh Environmental \\ Performance terhadap Environmental Disclosure}

Pengujian hipotesis keempat menunjukkan bahwa environmental disclosure berpengaruh positif terhadap environmental disclosure. Hasil itu terbukti dari nilai $\mathrm{t}$ yang dihasilkan sebesar 3,169 dengan tingkat signifikan 0,002 yang berarti lebih kecil dari 0,05 . Hasil penelitian ini sesuai dengan penelitian yang dilakukan oleh Suranto et al. (2006), Clarkson, et al. (2007) dan Al-Tuwaijri et al. (2004) yang menyatakan environmental performance berpengaruh positif signifikan terhadap environmental dislcosure. Dengan demikian, dapat diambil kesimpulan bahwa semakin baik predikat perusahaan memperoleh nilai environmental performance maka semakin lengkap dan baik perusahaan melakukan environmental disclosure.
Hal ini mengindikasikan bahwa perusahaan manufaktur berlomba-lomba untuk memperoleh predikat yang baik untuk kinerja lingkungan sehingga akan berdampak pada environmental disclosure. Hal ini sesuai dengan Peraturan Kementrian Lingkungan Hidup yang mengharuskan perusahaan untuk berlomba memperoleh predikat yang baik. Selain itu, untuk memberikan informasi mengenai tanggung jawab perusahaan terhadap kepedulian lingkungan dan pengendalian pencemaran limbah perusahaan.

\section{Simpulan}

Berdasarkan hasil penelitian dan pembahasan, maka kesimpulan yang dapat diambil dari penelitian ini sebagai berikut:

1) Profitabilitas tidak berpengaruh terhadap enviromental disclosure.

2) Leverage tidak berpengaruh terhadap environmental disclosure.

3) Ukuran perusahaan berpengaruh positif environmental disclosure.

4) Environmental Performance berpengaruh positif terhadap environmental disclosure

\section{Keterbatasan}

Penelitian ini memiliki keterbatasan meskipun peneliti telah berusaha mengembangkan penelitian sedemikian rupa. Berikut adalah beberapa keterbatasan dalam penelitian ini yang masih perlu direvisi pada penelitian selanjutnya, yaitu: Berdasarkan data yang diperoleh dari sumber yang digunakan menunjukkan masih banyak data yang kurang lengkap sehingga memperkecil sampel yang digunakan. Dalam penelitian ini hanya 71 perusahaan selama tiga tahun (2014 sampai dengan 2016), hasil ini diperoleh setelah proses pengecekan atas data yang dikumpulkan yang 
semula berjumlah 140 perusahaan, Penelitian ini hanya menggunakan perusahaan manufaktur sebagai obyek penelitian sehingga obyek penelitian belum mencakup keseluruhan jenis perusahaan yang ada, model regresi linear dalam penelitian ini menghasilkan nilai adjusted $R$ square yang masih relatif rendah yaitu sebesar $0,340 \%$. Hal ini menunjukkan kemampuan variabel independen dalam menjelaskan variasi variabel dependen hanya $\quad 34,0 \%$ sisanya $66,0 \%$ dipengaruhi oleh variabel lain yang tidak diteliti, Penilaian terhadap index environmental disclosure terdapat kesulitan dan hanya mengasumsikan terkait beberapa perushaan yang kurang lengkap dalam memberikan informasi lingkungan.

\section{Saran}

Saran yang dapat diberikan peneliti untuk riset yang akan datang yaitu: penelitian berikutnya sebaiknya memperluas sampel penelitian dan pengujian pengamatan yang lebih lama sehingga dapat memberikan hasil yang lebih baik, model regresi linear dalam penelitian ini menghasikan nilai Adjusted $\mathrm{R}$ square yang masih relatif rendah yaitu $25,1 \%$. Oleh karena itu, terdapat kemungkinan penelitian selanjutnya untuk mencari variabel independen lain yang mempengaruhi environmental dislcosure. Penelitian selanjutnya hendaknya mengkaji ulang tentang penilaian index environmental dislcosure sehingga hasil penelitian akan lebih akurat

\section{DAFTAR PUSTAKA}

Al-Tuwaijri, S.A., Christensen, T.E. dan Hughes II, K.E. (2004). The Relations among environmental disclosure, environmental performance, and economic performance: a simultaneous equations approach. Accounting, Organizations and Society. Vol. 29: 447-471

Anggraini, R.R. 2006. Pengungkapan Informasi Sosial dan FaktorFaktor yang Mempengaruhi Pengungkapan Informasi Sosial dalam Laporan Keuangan Tahunan (Studi Empiris pada Perusahaan-Perusahaan yang terdaftar Bursa Efek Jakarta). Simposium Nasional Akuntansi IX (Padang).

Belkaoui, A., dan Karpik, P. G. 1989. Determinants of The Corporate Decision To Disclose Social Information. Accounting, Auditing and Accountability Journal. Vol. 2: 36-51.

Clarkson, P., Li, Y., Richardson, G., \& Vasvari, F. 2008. Revisiting the Relation Betweet Environmental Performance and Environmental Disclosure: An Empirical Analysis. Accounting, Organizations and Society, 33(4/5), 1-41.

Cormier, Denis dan Magnan, Michel. 1999. "Corporate Environmental Disclosure Strategies: Determinants, Costs and Benefits", Journal of Accounting, Auditing - Finance, Vol. 14, No. 4, pp. 429-451.

De Villiers, Charl dan Van Staden, Chris J. 2011. "Where Firms Choose To Disclose Voluntary Environmental Information", Journal of Accounting and Public Policy, Vol. 30, No. 6, pp. 504-525.

Deegan, C. 2002. The Legitimizing Effect Of Social And Environmental Disclosures: A 
Theoretical Foundation. Accounting, Auditing and Accountability Journal, Vol. 15. Page 282-311.

Dowling, J. and Pfeffer J. 1975. Organizational Legitimacy: Social Values And Organizational Behavior. Pacific Sociological Journal Review, Vol. 18. Page. 122-136.

Ekbas, Halil Emre. 2014. Company Characteristics and Environmental Disoclosure: An Empirical Investigation on Companies Listed on Borsa Isatanbul 100 Index.

Gladia, Prima dan Rahadja, Surya. 2013. Pengaruh Environmental Performance terhadap Environmental Disclosure dan Hard Environmental Disclosure Perusahaan. Ponegoro Journal Of Accounting, Vol 2, No.2, Tahun 2013.

Hackston, D., dan Milne, M.J. 1996. Some Determinant of Social And Environment Disclosures In New Zealand Companies. Accounting, Auditing \& Accountability Journal. Vol. 9: 77-108

Ingram, R. dan Frazier, K. 1980. "Environmental Performance and Corporate Disclosure". Journal of Accounting Research. Vol. 18. pp.612-622.

Jensen, Michael C., dan W. H. Meckling. 1976. "Theory of the Firm: Managerial Behavior, Agency Costs, and Ownership Structure." Journal of Financial
Economics. Vol. 3, No. 4. pp. 305-360.

Kasmir. 2011. Manajemen Perbankan. Edisi Revisi 2008. PT. Raja Grafindo Persada. Jakarta.

Lindrianasari. 2007. Hubungan Antara Kinerja Lingkungan Dan Kualitas Pengungkapan Lingkungan Dengan Kinerja Ekonomi Perusahaan Di Indonesia. JAAI, 11(2).

Patten, D.M. 1991. Exposure, Legitimacy, And Social Disclosure. Journal of Accounting and Public Policy, Vol. 10. Page. 297-308

2002. "The Relation Between Environmental Performance and Environmental Disclosure: a Research Note", Accounting, Organizations and Society. Vol. 27. pp.763-773.

Peraturan Menteri Negara Lingkungan Hidup No. 7 Tahun 2008. Program Penilaian Peringkat Kerja Perusahaan Dalam Pengelolaan Lingkungan Hidup.

Peraturan Menteri Lingkungan Hidup Nomor 3. 2014. Program Penilaian Peringkat Kinerja Perusahaan Dalam Pengelolaan Lingkungan Hidup (PROPERLH).

Putri, Areka Pratiwi. 2015. Pengaruh Karakteristik Perusahaan terhadap Environmental Disclosure on Company Website. Tesis, Universitas Sebelas Maret. Surakarta.

Roberts, C. 1992. "Environmental Disclosures: A Note on 
Reporting Practices in Mainland Europe". Accounting, Auditing and Accountability, 4, 62-7.

Safitri, Ayu. 2008. Pengaruh Profitabilitas terhadap Tingkat Pengungkapan Corporate Governance. Skripsi, Program Sarjana Jurusan Akuntansi Fakultas Ekonomi Universitas Diponegoro.

Sembiring, 2005. Karakteristik Perusahaan dan Pengungkapan Tanggung jawab Sosial: Studi Empiris pada Perusahaan yang tercatat di Bursa Efek Jakarta. Paper Presented at the Seminar Nasional Akuntansi, Solo.

Solihin, Ismail. 2009. Pengantar Manajemen. Jakarta. Erlangga.

Subramayam, K. R dan J.J Wild. 2010. Financial Statement Analysis. Jakarta. Salemba: Empat.

Sudaryano. 2006. Pengaruh Karakteristik Perusahaan dan Manajemen Laba terhadap Environmental Disclosure serta Pengungkapan Perusahaan sebagai Variabel Moderating. Jurnal Akuntansi, Universitas Trisakti

Suhardjanto, D., Tower, G., dan Brown, A.M. 2007. Indonesian Stakeholders' Perceptions on Environmental Information, Journal of the Asia-Pacific. Centre for Environmental Accountability, vol.14, no.4, pp.211.

2008. Environmental Reporting Practices: An Evidence From Indonesia. Jurnal Akuntansi dan Bisnis. Vol. 8: 33-46. 2010. Corporate Governance, Karakteristik Perusahaan dan
Environmental Disclosure. Jurnal Prestasi, Vol. 6. No. 1-Juni 2010. , dan Miranti, Laras. 2009. Indonesian Environmental Reporting Index dan Karakteristik Perusahaan. Journal of Akuntansi. Universitas Sebelas Maret Surakarta.

Suratno, I.B., Darsono, dan Mutmainah. 2006. Pengaruh Environmental Performance terhadap Environmental Disclosure dan Economic Performance (Studi Empiris Pada Perusahaan Manufaktur yang Terdaftar di Bursa Efek Jakarta Periode 2001-2004). Simposium Nasional Akuntansi IX (Padang). 